Article

\title{
Private-Public Partnership as a Tool to Promote Entrepreneurship for Sustainable Development: WWP Torrearte Experience
}

\author{
Ignacio De Los Ríos-Carmenado ${ }^{1, *}$, Mauricio Ortuño ${ }^{2}$ and María Rivera ${ }^{1}$ \\ 1 Planning and Management of Sustainable Rural Development Research Group, GESPLAN, \\ Universidad Politécnica de Madrid, Madrid 2-28040, Spain; maria.riveramendez@gmail.com \\ 2 School of Business Administration, Universidad Estatal de Guayaquil, Guayaquil 090150, Ecuador; \\ mauriciortuno2@gmail.com \\ * Correspondence: ignacio.delosrios@upm.es; Tel./Fax: +34-91-336-3685
}

Academic Editor: Giuseppe Ioppolo

Received: 9 December 2015; Accepted: 17 February 2016; Published: 24 February 2016

\begin{abstract}
There is growing interest in the ability of both private-public partnerships and entrepreneurship to promote sustainable rural development. This research outlines the historical chronology and the importance of the PPP (Private Public Partnership) for rural entrepreneurship; the complexity of PPP management dimensions is also analyzed. In addition, this research is based on an empiric study of a PPP for entrepreneurship in sustainable development in the North Highland of Madrid's community, with more than 20 years of experience. This PPP is managed according to the Working With People (WWP) model, which is for the management of complex projects in the sustainable rural development field, and aims to promote the development of competences amongst the parties involved. The results show the positive effects in terms of entrepreneurship's competences for sustainable rural development and the parties involved who create the PPP management model for entrepreneurship and the Torrearte Project.
\end{abstract}

Keywords: private-public partnership; sustainable rural development; entrepreneurship; project management; competences

\section{Introduction}

Private-public partnerships (PPP) originate when two or more organizations in the public or private sector start a new cooperative relationship based on mutual trust, rather than being characterized by a hierarchical structure [1]. This organization is preceded by a number of positive connotations, such as a PPP being considered as a tool that "creates synergies" [2], that develops and strengthens competences [3], that creates alliances between various actors [4,5], and allows voluntary cooperation for financing and project management in many sectors [6-8]. It is also believed that, through its methodology, it has been able to overcome the social and technical complexities of rural development projects and natural resource dynamics [5,9-12].

The first steps for the consolidation of PPPs date back to the times when the Italian City-States were being constructed prior to the 16th Century, or to the 18th Century Dutch Golden age, where public institutions and the way they combined political interests with the private sector were the key aspects in generating economic booms [13]. Later in 19th Century England, the commercial and economic associations combined private and public interests, causing unprecedented economic growth and commercial expansion that made the Empire the world's top global economy [14]. In the 20th Century, at the United Nations conference on the Human Environment that took place in Stockholm 1972 [3], the PPPs were considered as important development instruments [3]. Given the failure of 
quantitative development models with top-down approaches, since the early 1990s, the most developed societies searched for new values and tendencies that promoted cooperation between agents in order to foster entrepreneurship $[6,15,16]$. This new approach is known as "postmodernity" $[6,15,17]$, and PPPs are linked to postmodernity, which purports government inefficiencies and hence justifies the involvement of the private sector to complement public efforts under free market economies [12]. This new ideological-cultural philosophy [18] resulted in important changes in the conception of what rural areas really are [5,19], as development is not only based on industrialization [20]. This vision incorporated other values that culminated in Europe with the Cork Declaration titled "A living rural sector" (Cork Declaration, 1996). Based on the Declaration's principles, rural development became the second pillar of the European Union Common Agricultural Policy.

In this context, the European Union aimed to address rural development with the creation of new participative structures within local governments focused on generating projects devised from the rural communities themselves [15]. In many European areas the creation of these new partnerships are considered as innovative tools [15] that have strengthened the bottom-up approach and promoted social participation [21]. The bottom-up approach applied in rural development originated with the LEADER programs in order to address the problems that affect rural communities. Out of this first form of PPPs, other tools emerged, such as: Country Enterprise Boards (CEBs) created to promote the culture of entrepreneurship as well as to advise and assist small businesses; and Local Partnership Companies (LPCs) that focus on disadvantaged groups, fight social exclusion, provide assistance to unemployed people and specific groups, generate opportunities, promote continuous training and the empowerment of communities [6,22]. Entrepreneurship has been seen as a self-employment opportunity, and as a key factor that positively influences the economy, generating jobs and acting as a catalyst for innovation. Schumpeter in 1934 [23] was the first in identifying innovation as a key factor for economic development. Shane and Venkataraman [24] conceptualize entrepreneurship as a process of identifying, evaluating and exploiting opportunities. It is this opportunity that is the starting point in the entrepreneurial process [25]. Through PPPs, the "innovative entrepreneurs" Schumpeter refers to, increase their ability to identify those opportunities other have not seen [26]. Innovation and an entrepreneurial spirit contribute to an improvement in competitiveness in the area, generating economic growth and contributing to the development of the local community [27].

At an international level, PPPs began being consolidated as development instruments when Agenda 21 was adopted in Rio de Janeiro, Brazil, 1992, in which new perspectives were agreed upon on issues such as the environment, economy and the social system [28]. At the following World Economic Forum held in Davos, Switzerland in 1998, the secretary-general Kofi Annan stated the importance of PPPs, stressing the need for the public, private and social sectors to work together in order to achieve prosperity [29]. In 1999, this same forum celebrated a World Pact where the voluntary incorporation of the private sector into development associations was promoted. In 2002, at the World Summit for Sustainable Development in Johannesburg and at the International Conference on Financing for Development held in Monterrey, Mexico, the creation of PPPs was promoted as a tool for achieving economic, social and environmental development [29].

Because of their history and importance in promoting sustainable rural development, PPPs have often been considered as the 21st Century cooperation paradigm [7]. To understand this PPP system, it is important to study and evaluate methodologies and the project's complexity [20]. Project management has become a tool that allows people to determine the size and the uncertainty of the PPP projects [5,21,30], the interrelationship and interdependence between the parts of the project [30-32], and the complexity and interaction with the context $[30,32,33]$. This PPP complexity analysis is based on its components: technological, structural, organizational and social [32,34]. Technological complexity refers to the group of activities or duties needed to obtain the final product [35]. Structural complexity of the PPP project relates to the temporary aspects of the project [36]; organizational complexity deals with the interdependence amongst the operational elements of the PPP [35,36]. Finally, social complexity, which integrates behavioral competences with values and ethics, considered 
as the most suitable elements to overcome possible moral conflicts relating to the parties involved in the PPP project $[32,34]$.

Different research has demonstrated that the main complexity factors in sustainable rural development and project management come from the social and contextual dimensions [37]. Analyzing and being aware of complexity factors has also been proven to be a necessary step to achieve adequate sustainable management. Complexity within sustainable development project management was born as an attempt to resolve complex problems based on new conceptual frameworks and tools that integrate a wide range of technical disciplines, such as planning, management and social sciences. The social complexity of the PPP is directly related to the ethical-social component of the Working With People (WWP) model, which intends to show the need to overcome the technical vision of a project, focusing on individuals' behavior and the context in which they work. It is envisioned to value the improvement of human behavior achieved by the agents involved. This model includes the behaviors, attitudes and values of people who interact to promote and manage projects [38].

Over the past few years, there have been new tendencies that aim to analyze complexity in project management. For example, the Cynefin Framework, which was introduced in 1999 by David Snowden [39] and is considered one of the first practical applications of the theory of complexity to the science of project management; and the Global Alliance for Project Performance Standards (GAPPS) [40], which is a volunteer driven, non-profit alliance that includes government, industry, professional associations, national qualification bodies and training/academic institutions who work to facilitate the mutual recognition and transferability of project management standards and qualifications by providing the global project management community with a reliable source of comparative information.

These new tendencies-Cynefin and GAPPS-together with the conceptual framework "Working With People" as a tool to promote PPPs allow us to synthesize and categorize entrepreneurs' competences for sustainable development across three interrelated dimensions: technical-entrepreneurial, political-contextual, and ethical-social. A key element of the WWP conceptual framework is "social learning" $[27,38]$. The name itself, Working With People, indicates the importance of learning from one another by working together and it covers the need to overcome the traditional technical-economic vision of project management in rural development by focusing attention on individuals' behavior and the context. These new elements make project management a complex process where all the different values, interests, appreciations, needs, expectations and commitments of each person play a role. Therefore, this conceptual framework results from the balance between three dimensions of competences: technical, behavioral and contextual [38].

Subsequently, it uses this WWP model to analyze 20 years' experience of a PPP project process in the northern territory of Madrid (Spain). This PPP (Torrearte) was built around the WWP process approach in order to empower people as well as to achieve a balanced role amongst actors in the four areas of the social relationship system-political, public, private and social-by building on the following principles and values: (a) respect for and primacy of the people; (b) guarantee of social well-being and sustainable development; (c) bottom-up and multidisciplinary approach; and (d) endogenous and integrated approach [38]. The analysis is carried out through a qualitative examination of the development process of the PPP, its functions, organizational structure, objectives and results. While there is much evidence that the PPP Torrearte, in the mountain areas of Madrid, can be considered successful as an effective tool to promote entrepreneurship for sustainable development, there have been significant problems in managing a process approach that provide potential lessons to promote entrepreneurship for sustainable development and solve the socioeconomic problems of this territory. In its conclusion, the paper highlights a number of important findings about how PPP approaches might be understood and operationalized more effectively in the future.

The different parameters used are based on the WWP framework, which is used to assess the different dimensions of complexity in the Torrearte project and to explore the project management competences, which helped define the following hypothesis for this PPP experience: 
- H1: PPPs are an effective tool to promote entrepreneurship for sustainable development (Entrepreneur Project for Sustainable Rural development (EPSRD)).

- H2: PPPs promote the development of personal competences that support entrepreneurship for sustainable rural development.

Each hypothesis is analyzed based on the WWP framework [38], and results are then categorized into its dimensions. H1 is demonstrated through the analysis of the evolution process of the PPP Torrearte S.L. in the three dimensions of the WWP, and H2 mainly corresponds to the ethical-social dimension as an assessment of the effects of the Entrepreneurs' Projects on the behavior competences for sustainable development.

\section{Experimental Section (Methodology)}

The results of this research are based on a methodology that incorporates different tools and information sources, primarily the collection and review of numerous secondary sources (scientific literature and historic information) on the above concepts. Moreover, the research methodology incorporates empirical information obtained from a PPP project for rural entrepreneurship, of social complexity in its management and implementation.

\subsection{Case Study: PPP Torrearte (Entrepreneur PPP for Sustainable Rural Development)}

The PPP is located in the Community of Madrid, Spain-and is implemented and managed since the beginning based on the planning model "Working With People WWP" [41,42]. Since 1994, the PPP Torrearte project has been developing a planning as social learning model based on the interactions between the various agents, which has provided public and private resources in order to implement the projects within the region.

The expertise and experience become integrated into actions under the WWP approach, which through participation and dialogue with the affected population have demonstrated that this model offers a long-term, sustainable approach [42].

This research begins with the analysis of the PPP Torrearte, which throughout these 20 years has generated an endless number of positive effects to improve social structure amongst the population and achieve competitive and sustainable performance. With the objective of analyzing the effectiveness of PPPs on promoting rural entrepreneurship over time and the impact of PPPs on the stakeholders involved [32], data gathering fieldwork was carried out. The secondary data examined mainly consisted of records, budgets, and historical archives found within the local town hall. The PPP Torrearte started in 1994, under the Rural Development Program (RDP) of the then Regional Government of the Mountain Areas of Madrid Board (PAMAM). Primary data was obtained through working closely with the local people, organizing workshops with all the different stakeholders in the area as well as different participative processes within the LEADER (Links between actions for the development of the rural economy) program with Local Action Group. The participatory workshops and social learning processes between actors coming from the four spheres of the social relationship system: political (Regional Community of Madrid and the 42 Local Governments), public administrative (PAMAM, Madrid Board for Mountain Areas) and different government managers), private-business and civil society (GALSINMA, Local Action Group of the Sierra Norte). Interviews with entrepreneurs and various sectors' representatives were also carried out.

\subsection{Data Collection: Tools and Protocols}

To conduct this research in an ethical manner an informed consent process was carried out with all the people that were interviewed or participated in the workshops. They were all previously informed about the nature of the research and its aims, as well as the data collection method that was going to be used, so that they could decide freely whether they wanted to participate in the process. Honesty and integrity were the core values behind the whole research through seeking to 
ensure the safety, dignity, wellbeing and rights of those associated with the research, while effectively and transparently managing any conflicts of interest [43]. For the collection and systematization of expert knowledge and experience regarding the project (qualitative and quantitative data), we used two complementary tools described below. A first tool, questionnaire (Table 1), was designed to assess the PPP entrepreneurs project's impact on the behavioral skills of the parties involved. For the design of this questionnaire, we considered psychometric models [44], and tools to assess skills for sustainable project management [45-47]. This tool has already been applied to other PPPs in Spain [32], reaching a total of 613 entrepreneurs. It considers seven behavior skills for project management: communication (1); negotiation, conflicts and crisis (2); creativity (3); teamwork (4); leadership (5); planning (6); and appreciation of values and ethics (7). This questionnaire was sent to the 26 Torrearte entrepreneurs, obtaining a response of $85 \%$ ( 22 owners), which is highly acceptable statistically speaking [46], and therefore required no further increase in the sample size. They were all from around the Torrearte Facilities. These entrepreneurs have collaborated and participated directly or indirectly in PPP management and implementation tasks, including the members of the Board as well.

Table 1. Questionnaire: Assessment of the effects of Entrepreneurial Projects on the behavioral competences for sustainable development.

\begin{tabular}{|c|c|}
\hline Skills & Items \\
\hline Communication & $\begin{array}{l}\text { I have learned to communicate with others and listen with an open and } \\
\text { positive attitude. } \\
\text { I have learned to communicate consistently and in a timely manner. } \\
\text { I have learned that you should be careful when deciding who receives } \\
\text { the information. } \\
\text { It has helped me to adequately express my ideas, opinions or viewpoints. } \\
\text { It has helped me to talk in front of an audience. } \\
\text { It has helped me capture people's attention and make myself understood. }\end{array}$ \\
\hline Negotiation, conflicts and crisis & $\begin{array}{l}\text { It has helped me develop my ability to resolve conflicts and crises. } \\
\text { I've learned to control tension in stressful situations. } \\
\text { It has helped me discuss work issues through debate and consensus } \\
\text { with others. } \\
\text { I have developed my ability to negotiate and reach agreements. } \\
\text { It has taught me to intervene in the conflicts that arise between partners. } \\
\text { It has taught me to successfully complete the negotiations that I undertake. }\end{array}$ \\
\hline Creativity & $\begin{array}{l}\text { I have improved my ability to generate ideas and solve problems. } \\
\text { It has taught me to take the lead in establishing relationships with others. } \\
\text { It has helped me deal with difficult situations as challenges to overcome. }\end{array}$ \\
\hline Teamwork & $\begin{array}{l}\text { It has increased my effort to find out how other partners in the project } \\
\text { are working. } \\
\text { It has increased the time I dedicate to understanding my organization } \\
\text { (Community). } \\
\text { It has encouraged me to be curious about many things around me. } \\
\text { It has helped me know how to guide my colleagues in their activities. } \\
\text { It has helped me relate to stakeholders. } \\
\text { I have learned to consult with others and consider their proposals } \\
\text { and views. }\end{array}$ \\
\hline Leadership & $\begin{array}{l}\text { I found that I would like to assume more important duties. } \\
\text { I discovered that I am a reference for others in carrying out certain activities. } \\
\text { I have developed my ability to give directions to others by helping them to } \\
\text { set goals. } \\
\text { During the activities in the project I prefer to take the lead. } \\
\text { I have improved my leadership skills, influencing the actions of } \\
\text { others effectively. } \\
\text { I have provided leadership and motivation to others. }\end{array}$ \\
\hline
\end{tabular}


Table 1. Cont.

\begin{tabular}{ll}
\hline \multicolumn{1}{c}{ Skills } & \multicolumn{1}{c}{ Items } \\
\hline \multirow{3}{*}{ Planning } & It has helped me plan what I have to do. \\
& It has helped me generate, analyze and select different alternatives. \\
& It has helped me consider the costs and benefits of the tasks performed. \\
& It has helped me coordinate work teams. \\
\hline & I improved my ability to consider the interests of others. \\
& It has helped me to further consider and respect ethical values. \\
It has helped me be more transparent and impartial in the defense of \\
ethical issues. \\
and ethics \\
It has helped me rejoice at the success of others. \\
It has helped me confirm that it is worth working in a community like mine. \\
It has helped me discover that people like to work with me forming a team. \\
It has helped me improve relations with each of my companions.
\end{tabular}

Source: Prepared by the authors based on the sources used.

A second tool, a Focus Group workshop was held [48] including the PPP Director and other key actors, applying the same criteria of questionnaire to analyze the PPP management dimensions for entrepreneurship and assessment of the effects on the competences of the parties involved.

To measure the reliability of questionnaire, the Cronbach alpha rate was used [49-51], eliminating items that were not sufficiently reliable from the statistical analysis [52].

The Likert attitude scale (1932), commonly used in social sciences to assess perceptions and quantitative aspects from the agents was used. The rating scale is constructed based on a number of items that reflect a positive or negative attitude about a stimulus or reference. Each item is structured with five answer options-strongly agree (4), agree (3), neutral (2), disagree (1) and strongly disagree (0)—giving the most favorable attitude the highest score [32].

The Statistical Package for the Social Sciences (SPSS) (V. 19, IBM, New York, NY, USA) was used for quantitative data analysis. The interaction of results between the knowledge of the affected population that was examined [53] with the expert knowledge of the planning group [54,55] allows us to learn and then adapt processes when required.

Hypothesis two was demonstrated through the analysis of the evolution process of the PPP Torrearte and its effects on the number of people in the area, as well as the number of entrepreneurs. The information used for the analysis of the process came from "working with people" [41], which offers a long-term sustainable approach and positive view of the reality, allowing actions to be taken with a better perspective of success in terms of the possibility of responding appropriately to the needs of the population.

\section{Results and Discussion}

This section aims to shed light on the evolution and processes followed by the PPP Torrearte to promote rural entrepreneurship in the territory. The results are divided into three sections according to the Working With People framework on which this PPP is based-ethical-social, technical-entrepreneurial and political-contextual—which interact through social-learning processes for sustainable performance [41]. These three components include the four areas of social-relations system — political field, public administration field, private and entrepreneurial fields and Civil Society field-as a synthesis of the PPP society model [56]. The apparent simplicity of WWP projects involves a large amount of complexity due to the richness of relationships and learning that occurs between the three types of agents of the proposed PPP-WWP model (Figure 1), where the three components must be present in any entrepreneur project designed from the PPP-WWP approach, interactions and overlaps between them through social learning processes. 


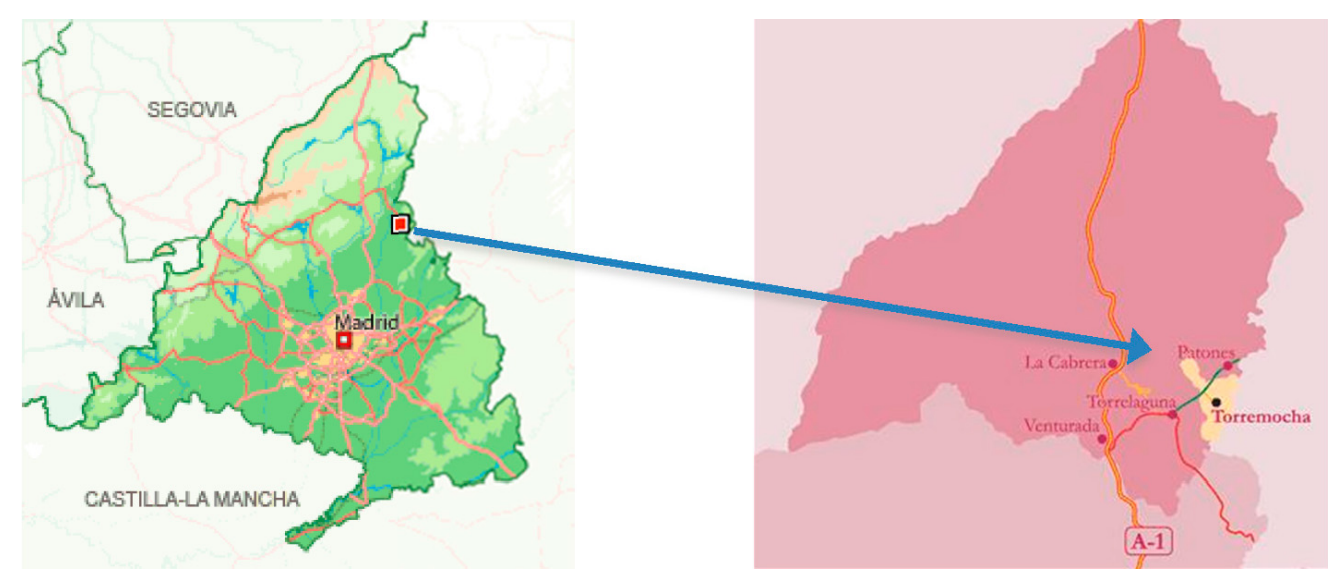

Figure 1. Location of the PPP (Private Public Partnership) Torrearte (Entrepreneur Project for Sustainable Rural development) in the North Community of Madrid (Spain).

\subsection{Political-Contextual Dimension of PPPs: Performance for Building Alliances}

This PPP dimension is to provide the Entrepreneurs Projects with key elements in order to meet the needs of the context in which the project is based. This area covers the ability of Entrepreneurs Projects to establish relations with political organizations and with the different public administrations. This ability to establish relations with the context depends on the acquisition of an internal organization for linking value creation to PPP performance, on the basis of endogenous resources and social mobilization. This dimension is divided into two sections to clearly illustrate the context in which the Torrearte PPP was created as well as how and why it was created and evolved.

\subsubsection{Context in Which the PPP Model is born}

The Regional Government of Madrid, aware of its competences under sustainable rural development policies within the EU, established its own policies for the mountain areas in 1985. Law 7/1985 of 2 April of the Local Regime states "due to the special problems posed by the mountain area called Sierra Norte, the Community of Madrid promotes and encourages the creation of associations between Municipalities in the area, with the aim of ensuring the principles of solidarity and inter-balance". To achieve this, in 1986, the Regional Government embarked on the task of identifying new ways to initiate dialogue and closer working relationships with the private sector and civil society through the creation of the Mountain Areas of Madrid Board (PAMAM Law 9/1986) as an agency of the Presidential Council of the Sierra de Madrid area.

A dual strategy was set up under this law in the mountain territories of the Community of Madrid. The first part aims to promote the integral development of mountain territories, whose physical and social conditions provide particular difficulties for human activities. The second strategy consisted of launching a new specific legal mechanism for this particularly problematic mountain area (Sierra Norte) where there are 42 local governments. While all other mountain areas of Madrid have found ways of subsistence through rural-urban relations and innovative enterprises related to rural tourism, nature, sports and services, due to its relief and communication difficulties, the Sierra Norte territory has historically been left behind with regards to these innovation currents. However, the Sierra Norte area possesses most of the water resources in the Community of Madrid.

This is why, through the PAMAM, the area has received special treatment through more qualitative interventions aimed at promoting endogenous development and sustainable initiatives. Considering the fact that each territory has to find its own development strategy, and for this needs the participation of private sector actors, the PAMAM developed a comprehensive model that included the participation of private sectors and other key actors from the 42 Local Governments of Sierra Norte. To design 
the Regional Plan, the PAMAM counted with the support of a multidisciplinary planning team called GESPLAN.

The model was a true multidisciplinary association that consisted of participatory planning coordinated by a university, the regional public administration, civil society, and private business sectors. The model was coined later with the phrase "Working With People (WWP)", which is understood as a professional practice developed by a team and that aims to connect knowledge and action through a common project, which in addition to the technical value of the projects incorporates the value of the people that participate and develop during the planning process [15]. To work under this approach, planners were required to possess, on top of technical and contextual competences, a special social sensitivity, and strong ethical standards [57]. This model prioritized initiatives born from interaction and social learning processes between actors coming from the four spheres of the social relationship system: political (Regional Community of Madrid and the 42 Local Governments), public administrative (The PAMAM and different government managers), private-business (which comprises all economic activities of private initiative in the territory) and civil society (GALSINMA, Associations of the Sierra Norte and other agents not included within the above subsystems).

The ultimate goal of this PPP model was to have an overall vision of the challenges facing sustainable rural development in order to undertake new projects and sustainable initiatives. The public-private collaboration for finding incentives and mutual benefits was promoted by the planning team through joint working. While companies seek economic benefits, local governments and nonprofit organizations allow the model to reach a balance with social and environmental criteria that ensure the success of the best enterprises.

\subsubsection{Creation of the PPP Torrearte (Entrepreneur Project for Sustainable Rural Development)}

At the end of 1994, the local government of Torremocha del Jarama-63Km North of Madrid-assumed leadership for the launch of a new PPP experience that aimed to promote civil society entrepreneurship initiatives. This project (Entrepreneur Project for Sustainable Rural development) was part of the sustainable rural development policies of the territory. The PPP was called Torrearte and it was put into place under the sponsorship of the Regional Government of Madrid authorities as well as the local city council of Torremocha.

The PPP model benefited from the competences of the multidisciplinary planning team Gesplan who provided services to the Regional Government and to the 42 Local governments of the North area of Madrid by implementing the WWP model [38]. This planning process ended in 2001 with the approval of the area's County Plan as the juridical tool that integrates and coordinates the Regional Government Council policies that affect this particular territory [4]. The Plan entailed a strategy to resolve the problems related with the demographic situation, activating SMEs, sustainable development and services management through participative coordinating mechanisms of public and private agents. The plan counted on strategic links that established the conditions to facilitate public-private alliances that facilitate the welcoming of potential settlers and entrepreneurs. Secondly, training areas for socio-labor integration and professional reintegration that support new entrepreneurial initiatives were established, articulating synergies with other regional projects.

During the process, there was a high level of participation from public and private agents involved and committed with the development of the North area of Madrid. The County Plan included actors from the 32 General Directorates of the Regional Government (from 10 different advisory councils) and representatives of the 8 bodies directly involved in the implementation of development policies in the territory [57]. Along the process, the creation of alliances and synergies for PPP projects was promoted, expanding the understanding of rural development to a set of broad measures that take into account people's worries and that fulfill productive, social and environmental functions.

The Torrearte PPP was the only alliance oriented specifically towards promoting entrepreneurship for sustainable rural development with an integrated and multisectoral approach. The Torrearte project allowed for the creation of synergies, not only within the County Plan itself but also with other regional 
and local programs under a sustainable rural development framework. Synergies were specially created with the Local Action Group of the Northern Territories of Madrid called GALSINMA under the LEADER II Programme framework 1994-1996 [15], and LEADER+ from 2000 to 2006. Synergies were also created with other community initiatives from structural funds (2000-2013) such as the Madrid Rural development Programme. This was the first time a Local Government of the Northern territories of Madrid was able to create synergies which were primarily targeted at entrepreneurship and development, achieving results across the various sustainability perspectives: social, economic and environmental.

The newly generated initiatives achieved success through a PPP collaboration model. At the end of the 1980s, the socioeconomic structural problems related to the demographic situation of Torremocha del Jarama were critical: the population was 217 inhabitants, economic activity was represented by just five companies, $60 \%$ of the population lived off agriculture, and because of migration and an ageing population, the school was about to close its gates (it closed in 1998). With the launch of the PPP Torrearte, synergies were achieved and the first entrepreneurial projects planned: a tree nursery, a Juvenile Detention Facility, a retirement home and a day center. These first projects and synergies resulted in the creation of new jobs and a fertile environment to generate new opportunities. In this context, the Local Development Agency of Torrearte S.L. is created (December 1994), formalizing a new PPP integrated in sustainable development policies and oriented towards civil society entrepreneurship. Figure 1 shows the development of the area from the year 1990 to 2011. When compared, it is possible to observe the increased housing in the territory, which indicates an increase in the population.

To solve the demographic problems and promote the creation of small enterprise for the sustainable development of the area, a 10-year strategic Plan was created (1994-2004), however it has not been updated since Torrearte, 1994. This rural development plan is composed of strategic pillars that establish, first of all, the availability of good infrastructure and public services to promote the reception of new residents and potential entrepreneurs. Secondly, a list of training areas needed to promote social-labor integration and professional reinsertion was created, and finally, a rural development strategic plan was produced in order to generate new entrepreneurship initiatives. According to the WWP model, the PPP Torrearte configuration ensures that entrepreneur projects allow for the adaptation of priorities amongst the people involved, also working with actors from the political and public administration fields. The PPP-Torrearte organization therefore has an instrumental character, to serve the population (entrepreneurships) and it is flexible and changing according to the learning and new information generated.

\subsubsection{Phases of the PPP-WWP Organization}

Since the establishment of Torrearte S.L in 1994, 3 phases have been identified, in which, a series of changes in the administration board can be observed. This was done with the aim of offering more representation to the different sectors. In the first phase (1994-2009), the board was represented by elected people voted for at the General Shareholders' Meeting, comprising of the mayor, councilor, secretary and municipal technician, as well as members of the business sector from Torrearte S.L and Asermut. In the second phase (2009-2012), through sitting minutes of the administrative board of Torrearte S.L it was decided that the council would be made up of people that had not been previously elected, and the Board named a president, vice-president, secretary and chairperson, community representatives who were characterized by their prestige in the area. A representative from the Association of business people of Torremocha was incorporated and the representative of Torrearte S.L. was maintained. In the third phase, the General Shareholders' Meeting decided to name the chairpersons to be part of the General Board while representing the administration council; therefore, former representatives of the different sectors were replaced by elected members. During this process the human factor was incorporated for decision-making [58]. The configuration of the PPP-Torrearte, based on the WWP approach, must ensure that organizational change processes and structural processes are generated to allow adaptation to the priorities of the people involved, also 
working with actors from the political and public administration fields. Therefore, the PPP-WWP organization has an instrumental character, to serve the population, and it is flexible and changing according to the learning and the new information generated. It is also necessary to consider that, in order to encourage sustainable rural development, the integration of all aspects of entrepreneurship (commercial, social and environmental) and the various social systems (political, administrative, and private) is required.

\subsection{The Technical-Entrepreneurial Dimension of PPPs: The Entrepreneur Projects for Sustainable Rural Development}

This dimension integrates the key elements required to make the entrepreneurs' projects investment units and technical tools capable of generating a flow of goods and services and meeting some targets, according to requirements and quality standards [34]. From the point of view of social relations, this component corresponds to the private-entrepreneurial field, which comprises all activities of private initiative (entrepreneurial). The PPP-WWP adopts a "business function" - as mobilizing human, economical, public, and private resources-leading to agreement and negotiation between various actors and involves a commitment to assume and manage risk [41].

\subsubsection{Entrepreneur Project Management Cycle (EPMC) for Sustainable Rural Development (EPSRD)}

Project cycle management is a participatory and creative process-as much art as science-involving the negotiation of decisions acceptable to key stakeholder groups (EU, 2014). From the beginning, the PPP-Torrearte adopted a particular Entrepreneur Project Cycle Management (EPMC) as a project management tool based on the WWP approach and a bottom-up process that includes the affected population and all the different phases and sectors present in the rural area.

During the different phases of the PPP project cycle, the Torrearte planning team provides technical advice for the proposal's final design, and it then gets channeled to the different sources of existing resources (PAMAM, MANCOMUNIDAD, Local Action Group GALSINMA and other Businesses). Teamwork, negotiation and communication skills are thus central to effective EPMC, as is an appreciation of the political context within which decisions are being made. The resources obtained from the approved projects are given entirely to the beneficiary of such project. EPMC provides an overall analytical and decision making framework, complemented by the application of other specific "technical" and "process" tools. This EPMC of operations for managing entrepreneurial projects has five phases, as shown in Figure 2 below. Figure 3 shows the municipality's evolution from the year 1990 to 2011.

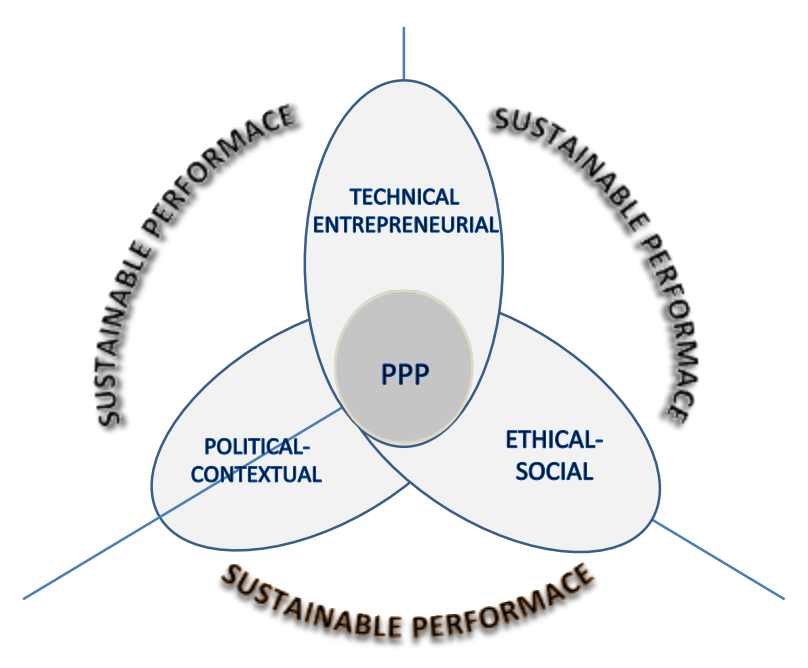

Figure 2. PPP Working with People (WWP) model. 


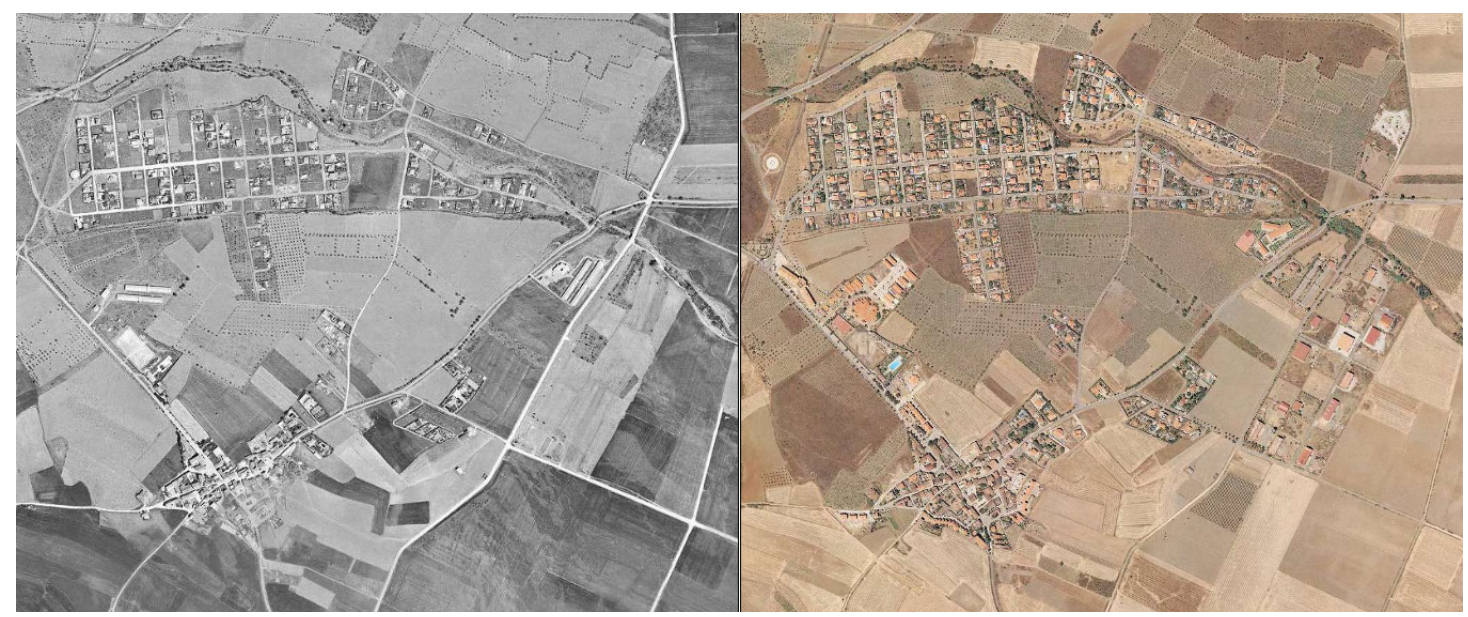

Figure 3. Municipality evolution: (left) 1990; and (right) 2011 (Source: Torrearte Municipality 2013).

The purpose of the Project Idea stage is to identify entrepreneurial project ideas consistent with needs, problems, opportunities and sustainable rural development priorities. The purpose of the Formulation stage (Pre feasibility, Feasibility and Final Project) is to confirm the relevance and feasibility of the entrepreneurial project idea, prepare a detailed project design, including the management and coordination arrangements and risk management. After the funding stage (financing proposal for individual entrepreneurial projects) the implementation stage of the project cycle is in many ways the most critical, as it is during this stage that planned benefits are delivered. All other stages in the EPC cycle are therefore essentially supportive of this implementation stage. In this implementation stage, the movement of resources is translated into a final product created from the entrepreneurial project. Although the technique is the basis, what is produced from the WWP project goes much further. We refer to the value of the "artwork" created by people working on the project, to its value as a unique product - made with perfection, mastery and harmony-and resulting from the integration of technical knowledge and skills [41]. This "artwork" is precisely what gives name to the PPP project "TORREARTE". Thus, it confers an aesthetic value to the products of entrepreneur PPP-WWP projects, which are the result of a "dialogue" of entrepreneurs (workers) with the work produced, inserting sensibilities and emotions, cultural values, historical references and linking the commercial and sociocultural topics. From this WWP approach, the technical-entrepreneurial component reaches its peak when entrepreneurs are able to put emotion into what they produce and create. With this approach, each PPP-WWP project, as a Technical-entrepreneurial investment unit, becomes an innovation, a unique experiment, and whatever its outcomes are, will always provide information to society [41]. Figure 4 shows the entrepreneur Project management Cycle. 


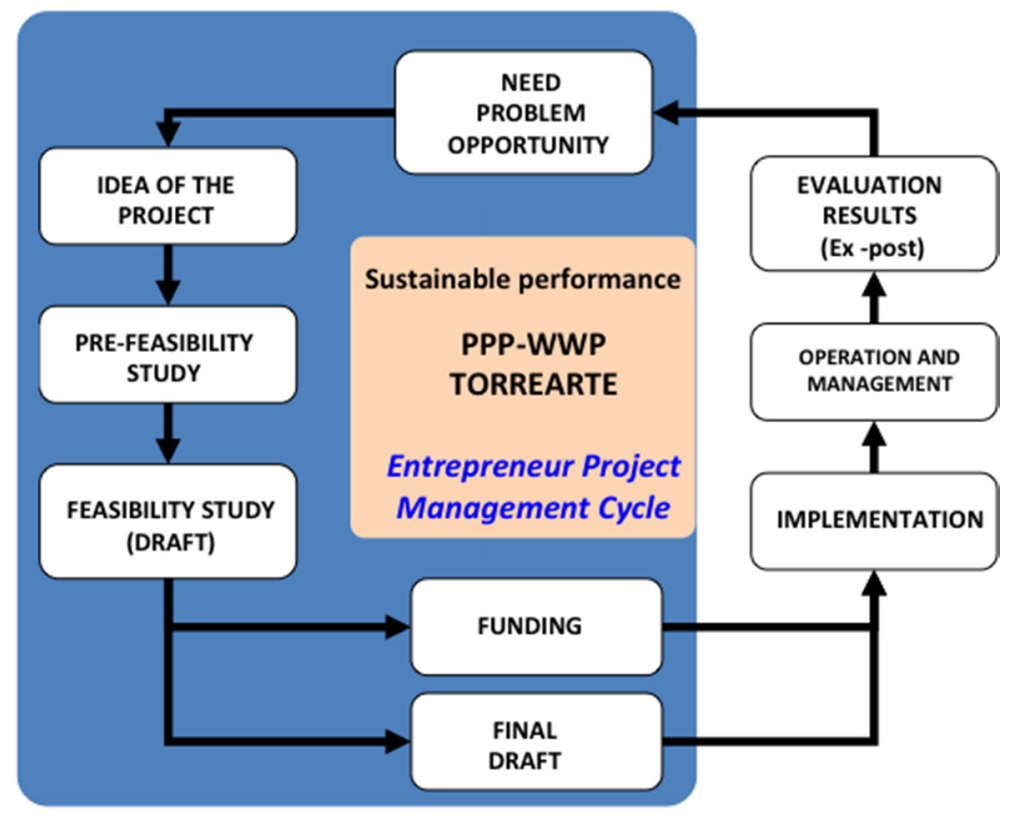

Figure 4. Entrepreneur Project management Cycle and WWP approach (Source: Cazorla et al., 2010).

In relation to the last phase of the project cycle, the PPP Torrearte does perform evaluations at a general level in order to determine the impacts of the projects as well as to make sure the goals of the Development Plan are met. The evaluation phase provides new information, enabling the incorporation of lessons learned into the decision-making process of PPP management.

The Administration Board is the body in charge of executing the development policies of the PPP Torrearte and it is within this board where there is space for participation and representation of the different sectors. By means of a public contest, Torrearte has outsourced the management to an external enterprise; since the year 2000 this enterprise has been "Torrearte initiatives" which has effectively fulfilled all objectives and goals established. Iniciativas Torrearte is in charge of recruiting administrative personnel (fiscal, accounting, labor manager) while the PPP Torrearte hires the technical and service personnel (technicians assigned to specific programs, etc.).

\subsubsection{Entrepreneur Projects for Sustainable Rural Development: Funding and Beneficiaries}

The PPP is based on the principle of planned negotiation, where the competences of the parties involved are identified building a common commitment [54]. This model goes beyond the economic and commercial results of the projects as its action range has a real impact on the development of tangible and intangible values that result from the negotiation capacity that involves listening and finding shared solutions [59].

From 1994 to 2011, the PPP Torrearte has developed an endless number of projects that have been made possible thanks to different financing institutions. The PPP Torrearte, as with other PPPs, has the potential of being the solution in overcoming public service's problem resulting from the increase of public demand and fiscal pressures. Generally, the public will greatly benefit from the participation of both public and private sectors in sustainably developing physical and social infrastructures [5]. They benefit both sectors since the PPP will bring in the skills, knowledge and efficiency of the private sector [60], and the public sector will have more resources to provide the public with additional services; while at the same time sharing the risk in the case of failure. Participation by both the public and private sectors allows them to learn from each other and create synergies in the implementation of projects. For this reason, the PPP Torrearte management is a mechanism to synchronize competing values of different stakeholders in pursuing commercial and social outcomes so as not to create tension and conflict in the partnership. 
The PPP Torrearte based on the WWP approach proposes that, in order to improve performance, partners involved in the PPP are required to integrate both commercial and social entrepreneurship in their pursuit of sustainable performance. The existence of both commercial and social entrepreneurship will lead to a balance of profitability and social responsibility [5]. Table 2 below shows the entrepreneur PPP projects as well as the financing sources. Entrepreneurship projects can be divided into two categories, namely commercial entrepreneurship and social-cultural entrepreneurship.

Table 2. A summary of Entrepreneur PPP types.

\begin{tabular}{ccc}
\hline Entrepreneur PPP Type & Channeled Value & No. Private Partner \\
\hline $\begin{array}{c}\text { Commercial entrepreneurships } \\
\text { Commercial (business } \\
\text { associations) }\end{array}$ & $19.09 \%$ & 14 \\
$\begin{array}{c}\text { Social and Cultural } \\
\text { entrepreneurship }\end{array}$ & $21.55 \%$ & 12 \\
Grand Total & $59.37 \%$ & 12 \\
\hline
\end{tabular}

Commercial entrepreneurship is defined as firm efforts to innovatively explore and exploit resources for rent-seeking purposes [61]. In the context of the PPP Torrearte, this commercial entrepreneurship is focused on the following areas and resources: advising service sector businesses, agro-food, aromatic plants, artistic entrepreneurship, bakery, training, craftwork, forest seeds, restaurant, cottage industries, snail farming, canned vegetables, drinks manufacturing, agricultural technologies, bee products, cooperatives of services, laundry and kitchens, craftwork entrepreneurships (arts, food), ships and warehouses.

On the other hand, social-cultural entrepreneurship is defined as the identification, evaluation and exploitation of opportunities that results in social values [62]. In the context of the PPP Torrearte, the social entrepreneurship focused on the following areas: advising the public sector, children and family services, commonwealth project, museum of local culture, environmental infrastructures, employment and professional training for women, youth housing, micro social entrepreneurship, social equipment, social headquarters and social services. In Table 2, commercial entrepreneurship, accounts for $41 \%$, which creates commercial value and social entrepreneurship represents $59 \%$, which helps civil society and firms to solve problems and needs.

Table 3, shows the projects as well as the financing sources and the beneficiaries of such capital.

Table 3. A summary of Entrepreneur PPP financing sources.

\begin{tabular}{lccc}
\hline \multicolumn{1}{c}{ Partnership } & Budget & \% Value & No. Alliances \\
\hline Commercial & $€ 3,473,680.00$ & $19.09 \%$ & 14 \\
Local Governments (Commonwealth) & $€ 480,000.00$ & $2.64 \%$ & 2 \\
GALSINMA Leader Program UE & $€ 2,768,000.00$ & $15.21 \%$ & 11 \\
Regional Government (PAMAM) & $€ 225,680.00$ & $1.24 \%$ & 1 \\
Commercial (business associations) & $€ 3,921,420.00$ & $21.55 \%$ & 12 \\
Local Governments (Commonwealth) & $€ 1,915,860.00$ & $10.53 \%$ & 4 \\
GALSINMA Leader Program UE & $€ 780,000.00$ & $4.29 \%$ & 2 \\
Regional Government (PAMAM) & $€ 1,225,560.00$ & $6.73 \%$ & 6 \\
Social and Cultural entrepreneurship & $€ 10,804,539.00$ & $59.37 \%$ & 12 \\
Local Governments (Commonwealth) & $€ 2,944,005.00$ & $16.18 \%$ & 4 \\
GALSINMA Leader Program UE & $€ 325,000.00$ & $1.79 \%$ & 2 \\
Regional Government (PAMAM) & $€ 7,535,534.00$ & $41.40 \%$ & 6 \\
Grand Total & $€ 18,199,639.00$ & $100.00 \%$ & 38 \\
\hline
\end{tabular}




\subsection{Ethical-Social Dimension: Competence Development}

This component covers the context of behavior, attitudes and values of the people who interact to promote, manage or direct the PPP-WWP project. The remit of the social system that surrounds the PPP Torrearte project is to cover people's conduct and moral behavior and it sets out the "foundations" to make people, both from private and public fields, work together, with a sense of commitment, confidence and personal freedom [41]. The incorporation of ethics means considering the PPP-WWP project as not something "neutral" but rather based on an ideal of service and guided by values. This PPP dimension integrates behavioral competencies with ethics and values as appropriate elements to overcome potential moral conflicts related to the parties involved in the projects [34]. This means ensuring that the organizations promoting the PPP have a culture that incorporates the ethical dimension [56].

The social system that surrounds the PPP Torrearte project and the municipality, through Torrearte, has strengthened its territorial identity built on an agricultural past. The creation of this solid and distinct image has gained the support of institutions and organizations to achieve the consolidation of the different areas of development, such as the agricultural heritage (Carrabus Channel, wheat industries, and the agricultural museum), craftwork (Torrearte "Otro Madrid") and artistic (Torrearte and Culture) social economy (Asermut, great house, barbol, kalima, etc.) public economy (Ag. D.L. Torrearte, S.L., AAT, S.L.) and ecologic agriculture (cereal dry lands and legumes).

\section{Effects of the Entrepreneurship Projects on Behavior Competences}

In order to assess the effects of the PPP projects on the competences of the beneficiaries, reliability analysis was used [32], to establish: results reliability, the filtering of the variables of each competence element-51 of 89 elements were eliminated-resulting in a survey with 38 questions with a global reliability of 0.94 . Subsequently, an exploratory factorial analysis was carried out through the least squared method [52], in order to obtain variable weighting charges and detecting the most important. The reliability of the competence elements can be observed in Table 4 .

Table 4. Reliability of the effects in the competences development.

\begin{tabular}{lcc}
\hline \multicolumn{1}{c}{ Competences } & Alpha & Items \\
\hline Leadership & 0.93 & 6 \\
Communication & 0.86 & 6 \\
Teamwork & 0.84 & 6 \\
Crisis and conflicts negotiation & 0.65 & 6 \\
Creativity & 0.55 & 3 \\
Ethics and values appreciation & 0.37 & 7 \\
Planning & 0.28 & 4 \\
\hline
\end{tabular}

The results after the application of the tool are shown in Table 5. All entrepreneurs agree that the project has allowed them to develop their behavior competences (with an average value of 3.04), with leadership, communication, negotiation, crisis and conflicts being the main competences, which the beneficiaries felt they had most improved. This information was adapted to determine the development of competences amongst the 16 entrepreneurs found within Torrearte S.L. 
Table 5. Assessment of the effects of the project Torrearte S.L. in skills development.

\begin{tabular}{lc}
\hline \multicolumn{1}{c}{ Competences } & Average Valuation \\
\hline Leadership & 3.75 \\
Communication & 3.50 \\
Negotiation. Crisis and conflicts & 3.50 \\
Creativity & 3.50 \\
Values and ethics appreciation & 2.81 \\
Planning & 2.63 \\
Teamwork & 2.44 \\
Average & 3.04 \\
\hline tion scale of 0-4: strongly agree 4, agree 3, neutral 2, disagree 1, strongly disagree 0.
\end{tabular}

By analyzing the answers, it can be seen that the most significant developments can be observed in the areas of leadership (3.75), communication (3.50), negotiation (3.50) and creativity (3.50). The high value given to these competences could be attributed to the participation of the entrepreneurs in all stages of the project. Leadership at the Torrearte PPP has been positively valued by entrepreneurs throughout all these years by demonstrating management transparency, equity, and, most of all, it has consolidated a clear view of the objectives to achieve the development plan. This competence is linked to others such as communication, which, by maintaining a horizontal level relationship among the involved sectors has facilitated the access to information regarding the different PPP units. Another competence comes as a result of excellent negotiations that have managed to invigorate other sectors such as the agro-industrial and agro-tourism sectors. This would have been difficult without this PPP. Finally, the creativity competence can be observed in the initiatives that have succeeded and managed to maintain themselves, even in times of a great depression. This competence has allowed the projects to achieve sustainability over time and to improve the quality of life of the settlers in the area.

\section{Conclusions}

Sustainability implies a new approach and new methods for implementing projects and programs that involve sustainable development objectives. On the other hand, the PPPs for rural development projects have large and long-term impacts on social, economic and environmental sustainability in rural territories. Therefore, the future of rural sustainability is dependent upon an interdisciplinary workforce and multisectoral approach with broad skills related to project and program management. At the basis of that, skills and education must be a core understanding of sustainability and the development of competences relating to project management to contribute to sustainability issues.

Over the past twenty years, the Research Group in Planning and Sustainable Management for Rural/Local Development (GESPLAN) of the UPM, the Regional Government of the Mountain Sustainability Areas of Madrid Board (PAMAM) and the Local Action Group of the Mountain Territories of Madrid (GALSINMA) has implemented a PPP model for rural entrepreneurship (Entrepreneur Project for Sustainable Rural Development). This PPP is managed from the WWP model, as a response to the regional (social, economic and environmental) problems.

The results of our ongoing self-efficacy assessments indicate that the WWP model has been highly effective in helping the entrepreneurs and rural practitioners to enhance sustainable rural development with an integrated and multisectoral approach for a living countryside.

The evolution of the Torrearte PPP is analyzed from the three WWP dimensions for Sustainable Rural Development. Firstly, within the technical-entrepreneurial dimension, it is possible to observe how the PPP has been able to acquire resources to modernize production processes and integrate sustainability principles through the creation of entrepreneur projects (commercial entrepreneurship and social-cultural entrepreneurship).

Within the political-contextual dimension, the PPP has managed to create employment, recuperate population, increase the number of people within the social security system and turned the municipality 
into a rural development success story for all the other Sierra Norte Municipalities to refer to. The PPP for sustainable development is about integrating the political and contextual goals (social, economic and environmental) that are interdependent and mutually reinforcing. The PPP Entrepreneur Project for Sustainable Rural Development can be treated as a way of expressing the broader expectations of society as a whole. Hence, it was necessary to understand the structural and organizational complexity that originates from the participation of the diverse agents of the territory within the Administration Council, advising the promotion of agrarian ecology programs, touristic projects, housing and infrastructure.

Finally, with the ethical-social dimension, it is possible to observe an increase in the participation of the different agents as well as an important improvement in the competences and abilities of the entrepreneurs involved in the different projects. We are therefore faced with a process where the WWP and its effect on the development of personal competences (behaviors, attitudes and skills) for project management is validated. The results show the positive effects in the entrepreneurship's competences for sustainable rural development and the parties involved that provide the PPP management for the entrepreneurship; especially their leadership and negotiation capacities, indicating their respective importance for a project's success and sustainability.

Throughout the 20 years of experience in managing these PPPs, the right approach of the WWP methodology for sustainable rural development is demonstrated. It extends much further than simply the "technical" aspects of the projects and emphasizing the behavior of individuals and the contexts in which they work. We find that stakeholders and project managers should also use a social integrative approach for "working with people" to provide balance amongst the three elements of sustainability. This WWP approach seeks to understand the nature of sustainability tensions along with how actors work through them, providing an opportunity to improve behaviors and competences for complex sustainability issues and generating creative approaches to them. The model has allowed the territory to experiment dynamism in economic activities, with small environmentally friendly entrepreneurial businesses, that have created local jobs, allowing new families to come and live in this rural area. This young population increase improves the viability and sustainability of entrepreneurs generating new expectations for life in rural villages. We can therefore conclude that PPPs with participative structures are a successful way of promoting entrepreneurship and innovation in rural areas.

Acknowledgments: We wish to express our sincere gratitude to Carlos Rivera, the Mayor of the Torremocha del Jarama and to Angel Cano Sanz of the PPP Torrearte for his valuable comments and suggestions. We also thankfully acknowledge support from the Regional Government of the Mountain Areas of Madrid Board (PAMAM) and from the Local Action Group of the Northern Territories of Madrid (GALSINMA) LEADER Programme EU.

Author Contributions: The individual contribution and responsibilities of the authors are listed as follows: Ignacio De los Ríos designed the research, developed the model and conducted model validation; Mauricio Ortuño collected the data and analyzed the data; Ignacio and Mauricio wrote the paper; and María Rivera revised the manuscript, provided some comments and helped edit the manuscript. All authors reviewed and approved the final manuscript.

Conflicts of Interest: The authors declare no conflicts of interest.

\section{References}

1. Naoum, S. An Overview into the Concept of Partnering. Int. J. Proj. Manag. 2003, 1, 71-76. [CrossRef]

2. McQuaid, R.W. The theory of partnership. In Public-Private Partnerships: Theory and Practice in International Perspective; Routledge: London, UK, 2002; pp. 9-35.

3. Mundial, F.E. Public-Private Partnerships: Meeting in the Middle; The United Nations Foundation: Washington, DC, USA; WEF: Geneva, Switzerland, 2003.

4. De los Ríos, I.; Alier, J.L.; Yague, J.L. El Plan Comarcal de la Sierra Norte de Madrid. Coordinación y Gestión del Desarrollo Sostenible en los Territorios de Montaña; PAMAM: Madrid, Spain, 2003. (In Spanish)

5. Sastre-Merino, S.; De los Ríos-Carmenado, I. Capacity Building in Development Projects. Procedia Soc. Behav. Sci. 2012, 46, 960-967. [CrossRef] 
6. Sastre-Merino, S.; Negrillo, X.; Hernández-Castellano, D. Sustainability of Rural Development Projects within the Working With People Model: Application to Aymara Women Communities in the Puno Region, Peru. Cuad. Desarro. Rural 2013, 10, 219-243.

7. Austin, J.E. Principles for partnership. Lead. Lead. 2000, 18, 44-51.

8. Xu, Y.; Peng, Y.; Qian, Q.K.; Chan, A.P.C. An alternative model to determine the financing structure of PPP-based young graduate apartments in China: A Case Study of Hangzhou. Sustainability 2015, 7, 5720-5734. [CrossRef]

9. Jamali, D. Success and failure mechanisms of public private partnerships (PPPs) in developing countries: Insights from the Lebanese context. Int. J. Public Sect. Manag. 2004, 17, 414-430. [CrossRef]

10. Kolk, A.; van Tulder, R.; Kostwinder, E. Business and partnerships for development. Eur. Manag. J. 2008, 26, 262-273. [CrossRef]

11. Miraftab, F. Public-private partnerships. The trojan horse of neoliberal development? J. Plan. Educ. Res. 2004, 24, 89-101. [CrossRef]

12. Muleba, N.; Royd, V. Impacts of Public-Private Partnership on Local Livelihoods and Natural Resource Dynamics: Perceptions from Eastern Zambia. Resources 2014, 3, 471-487.

13. Mokyr, J. Thinking about Technology and Institutions, Departments of Economics and History Northwestern University. In The Gifts of Athena: Historical Origins of the Knowledge Economy; Princeton University Press: Princeton, NJ, USA, 2002.

14. O'Brien, D. An Introduction to the Theory of Knowledge; Polity: England, UK, 2006.

15. Cazorla, A.; De los Ríos, I.; Díaz-Puente, J. The Leader community initiative as rural development model: Application in the capital region of Spain. Sci. J. Agro-sci. 2005, 39, 697-708.

16. Díaz-Puente, J.; Cazorla, A.; De los Ríos, I. Policy Support for the Diffusion of Innovation among SMEs: An Evaluation Study in the Spanish Region of Madrid. Eur. Plan. Stud. 2009, 17, 365-387. [CrossRef]

17. Marsden, D. The Impact of Industrial Relations Practices on Employment and Unemployment; OECD Jobs Study Working Papers 3; OECD Publishing: Paris, France, 1995.

18. Hörisch, J.; Edward, F.R.; Schaltegger, S. Applying Stakeholder Theory in Sustainability Management Links, Similarities, Dissimilarities, and a Conceptual Framework. Organ. Environ. 2014, 27, 328-346. [CrossRef]

19. Murdoch, J.; Pratt, A. Rural studies: Modernism, postmodernism and the "post rural". J. Rural Stud. 1993, 9, 411-427. [CrossRef]

20. Gladwin, T.; James, N.; Kennelly, J.; Krause, T. Shifting Paradigms for Sustainable Development: Implications for Management Theory and Research. Acad. Manag. Rev. 1995, 20, 874-907.

21. De los Ríos, I.; Díaz-Puente, J.; Cadena-Iñiguez, J. The initiative LEADER as a model for rural development: Implementation to some territories of México. Sci. J. Agrocienc. 2011, 45, 609-624.

22. Kearney, B. LEADER II Mid-Term Evaluation; Kearney and Associates: Dublin, Ireland, 1997.

23. Schumpeter, J.A. The Theory of Economic Development; Cambridge University Press: Cambridge, UK, 1934; Volume 55.

24. Shane, S.; Venkataraman, S. The promise of entrepreneurship as a field of research. Acad. Manag. Rev. 2000, 25, 217-226. [CrossRef]

25. Ozgen, E.; Baron, R.A. Social sources of information in opportunity recognition: Effects of mentors, industry networks, and professional forums. J. Bus. Ventur. 2007, 22, 174-192. [CrossRef]

26. Kirzner, I. Perception, Opportunity and Profit; University of Chicago Press: Chicago, IL, USA, 1979.

27. EMKF. Embracing Innovation, Entrepreneurship and American Economic Growth. Available online: http:/ / papers.ssrn.com/sol3/papers.cfm?abstract_id=1260355 (accessed on 17 February 2016).

28. Faulkner, J.H. Bridges to Sustainability. Business and Government Working Together for a Better Environment; Yale University: New Haven, CT, USA, 1997.

29. World Economic Forum. Women's Empowerment: Measuring the Global Gender Gap; The United Nations Foundation: Washington, DC, USA; WEF: Geneva, Switzerland, 2005.

30. Ioppolo, G.; Saija, G.; Salomone, R. Developing a Territory Balanced Scorecard approach to manage projects for local development: Two case studies. Land Use Policy 2012, 29, 629-640. [CrossRef]

31. Belout, A.; Gauvreau, C. Factors influencing project success: The impact of human resource management. Int. J. Proj. Manag. 2004, 22, 1-11. [CrossRef]

32. De los Ríos-Carmenado, I.; Guillén-Torres, J.; Herrera-Reyes, A.T. Complexity in the management of rural development projects: Case of LASESA (Spain). Int. J. Rural Dev. 2013, 10, 167-186. 
33. Geraldi, J.G.; Albrecht, G. On Faith, Fact, and Interaction in Projects. Proj. Manag. J. 2007, 38, $32-43$. [CrossRef]

34. IPMA. NCB 3.1 Bases para la Competencia en Dirección de Proyectos, Available online: http:/ /www.aeipro.com/ index.php/es/mainmenu-publicaciones / mainmenu-publicaciones-libros/223-ncb-30-bases-para-lacompetencia-en-direccion-de-proyectos (accessed on 17 February 2016). (In Spanish).

35. Baccarini, D. The concept of project complexity-A review. Int. J. Proj. Manag. 1996, 14, 201-204. [CrossRef]

36. Williams, T.M. The need for new paradigms for complex projects. Int. J. Proj. Manag. 1999, 17, $269-273$. [CrossRef]

37. Loorbach, D. Transition management for Sustainable Development: A prescriptive, Complexity-Based Governance framework. Governance 2010, 23, 161-183. [CrossRef]

38. Cazorla, A.; de los Ríos, I.; Salvo, M. Working With People (WWP) in rural development projects: A proposal from social learning. Cuad. Desarro. Rural 2013, 10, 131-157.

39. Snowden, D. The Social Ecology of Knowledge Management. In Knowledge Horizons: The Present and the Promise of Knowledge Management; Després, C., Chauvel, D., Eds.; Butterworth-Heinemann: Boston, MA, USA, 2000; pp. 237-265.

40. GAPPS (Global Alliance for Project Performance Standards). A Framework for Performance Based Competency Standards for Global Project Managers. Available online: https://www.google.com/ url?sa=t\&rct=j\&q=\&esrc=s\&source=web\&cd=2\&ved=0ahUKEwjCnI_IzIrLAhUF1SwKHZL wCyAQF ggnMAE\&url=http $\% 3 a \% 2 f \% 2$ fglobalpmstandards.org $\% 2$ fwp-content $\% 2$ fuploads $\% 2 \mathrm{f} 2015 \% 2 \mathrm{f} 04 \%$ 2fGAPPSSponsor-Framework-V1.pdf\&usg=AFQjCNFPr1I2vxOJOgfsjB_QtYlgxQyyjA\&sig2=ZQ5ypHMOt 6IKloc617lJVA\&bvm=bv.114733917,d.bGg\&cad=rja (accessed on 17 February 2016).

41. Cazorla, A.; De los Ríos, I. Rural Development as "Working with People": A Proposal for Policy Management in Public Domain; Archivo Digital UPM: Madrid, Spain, 2012; p. 29.

42. Cazorla, A.; De los Ríos, I.; Hernández, D.; Yagüe, J. Working with people: Rural development with Aymaras communities of Perú. Ageng. In Proceedings of the International Conference on Agricultural Engineering, Clermont-Ferrand, France, 6-8 September 2010.

43. Manuel, G.Á. Ética y Formación Universitaria: Aspectos éticos de la Investigación Cualitativa; Centro del Altos Estudios Universitarios: Madrid, Spain, 2002; pp. 85-103. (In Spanish)

44. Fouad, N.A.; Grus, C.L.; Hatcher, R.L.; Kaslow, N.J.; Hutchings, P.S.; Madison, M.B.; Crossman, R.E. Competency benchmarks: A model for understanding and measuring competence in professional psychology across training levels. Train. Educ. Prof. Psychol. 2009, 3, 5-26. [CrossRef]

45. Davies, A.; Hobday, M. The Business of Projects; Cambridge University Press: Cambridge, UK, 2005.

46. Hodgson, D. Disciplining the professional: The case of project management. J. Manag. Stud. 2005, 39, 803-821. [CrossRef]

47. Cea, M.A. Metodología Cuantitativa: Estrategias y Técnicas de Investigación Social; Centro de Investigaciones Sociologicas: Madrid, Spain, 2001. (In Spanish)

48. Madriz, E. Focus Groups in Research. In Thousand Oaks: Sage, Collecting And Interpreting Qualitative Materials; Denzinand, N.K., Lincoln, S., Eds.; SAGE Publications: Thousand Oaks, CA, USA, 2003; pp. 363-388.

49. Cronbach, L.J. Coefficient Alpha and Internal Structure of a Test. Psychometrika 1951, 16, 297-334. [CrossRef]

50. Fernández, J.A.; Rancaño, I.; Hernández, R. Propiedades psicométricas de la versión española del cuestionario Pecvec de perfil de calidad de vida en enfermos crónicos. Psicothema 1999, 11, 293-303. (In Spanish).

51. Yang, L.R.; Huang, C.F.; Wu, K.S. The Association among Project Manager's Leadership Style, Teamwork and Project Success. Int. J. Proj. Manag. 2011, 29, 258-267. [CrossRef]

52. Abad, F.J.; Olea, J.O.; Gil, V.P.; García, C.G. Medición en Ciencias Sociales y de la Salud; Madrid, S., Ed.; Editorial Sintesis SA: Madrid, Spain, 2011. (In Spanish)

53. Hulme, D. Learning and not learning from experience in rural project planning. Public Adm. Dev. 1989, 9, 1-16. [CrossRef]

54. Argyris, C.; Schön, D. Organizational Learning: A Theory of Action Perspective; Addison Wesley: Boston, MA, USA, 1978.

55. Friedmann, J. Empowerment: The Politics of an Alternative Development; Basil Blackwell: Cambridge, MA, USA, 1992.

56. Friedmann, J. Planning in the Public Domain: From Knowledge to Action; Princeton University Press: Princeton, NJ, USA, 1987. 
57. Cazorla, A.; De Los Rios, I. The new social sensibility in the Rural Developmet engineering. In Tampere (Finlandia): First International Join Work Shop on Rural Development Engineering. Rural Development Network; AGENG: Aarhus, Denmark, 2001.

58. Bond, R.; Hulme, D. Process Approaches to Development: Theory and Sri Lankan Practice. World Dev. 1999, 27, 1339-1358. [CrossRef]

59. Cazorla, A.; Friedman, J. Planificación e Ingeniería: Nuevas Tendencias; Taller de Ideas: Madrid, Spain, 1995. (In Spanish)

60. Kyvelou, S.; Karaiskou, E. Urban development through PPPs in the Euro Mediterranean region, Management of Environmental Quality. Int. J. 2006, 17, 599-610.

61. Ireland, R.D.; Webb, J.W. Strategic entrepreneurship: Creating competitive advantage through streams of innovation. Bus. Horiz. 2007, 50, 49-59. [CrossRef]

62. Haugh, H. A research agenda for social entrepreneurship. Soc. Enterp. J. 2005, 1, 1-12. [CrossRef]

(C) 2016 by the authors; licensee MDPI, Basel, Switzerland. This article is an open access article distributed under the terms and conditions of the Creative Commons by Attribution (CC-BY) license (http://creativecommons.org/licenses/by/4.0/). 